\title{
Effect of Alcohol on the Proestrous Surge of Luteinizing Hormone (LH) and the Activation of LH-Releasing Hormone (LHRH) Neurons in the Female Rat
}

\author{
Kathleen M. Ogilvie and Catherine Rivier \\ Clayton Foundation Laboratories for Peptide Biology, The Salk Institute for Biological Studies, La Jolla, California 92037
}

Reproduction is adversely affected by alcohol abuse in humans and laboratory animals. In rats, alcohol exposure suppresses both luteinizing hormone (LH) and sex steroid secretion, although consensus is lacking as to which level of the hypothalamic-pituitary-gonadal (HPG) axis is primarily affected. We tested the hypothesis that acute alcohol treatment inhibits the HPG axis by blunting release of LH-releasing hormone $(\mathrm{LHRH})$ in female rats, by examining the effect of this drug on the central reproductive endocrine event; i.e., the proestrous surge of gonadotropins, which triggers ovulation. In a first series of experiments, we injected alcohol at 8 A.M. and 12 P.M. on proestrus and measured plasma levels of $\mathrm{LH}$, estradiol $\left(E_{2}\right)$, and progesterone during the afternoons of proestrus and estrus. Alcohol administration blocked the proestrous surge of $\mathrm{LH}$ and ovulation. In subsequent experiments, alcohol inhibited the surge of LHRH (measured by push-pull cannulation) and $\mathrm{LHRH}$ neuronal activation (measured by Fos labeling in LHRH neurons). Because alcohol also decreased $E_{2}$ levels, we reasoned that it might have prevented positive feedback; however, alcohol retained its ability to inhibit the LH surge evoked by $E_{2}$ implantation in ovariectomized females, disproving this hypothesis. Additionally, alcohol does not act via increased corticosteroid secretion, because alcohol also blocked the proestrous surge in adrenalectomized females. Last, exogenous administration of LHRH to alcohol-blocked animals evoked LH secretion and ovulation, indicating that pituitary and/or ovarian function could be restored by mimicking the hypothalamic signal. Collectively, these data indicate that in female rats, alcohol inhibits the gonadotropin surge primarily by decreasing $\mathrm{LHRH}$ secretion.

Key words: luteinizing hormone; LH; luteinizing hormonereleasing hormone; $\mathrm{LHRH}$; gonadotropin-releasing hormone; $\mathrm{GnRH}$; alcohol; ethanol; proestrous
Chronic alcohol abuse has adverse effects on reproductive function in both men and women (for review, see Van Thiel and Gavaler, 1982; Mello et al., 1989, 1993). Animal models of alcohol exposure likewise document perturbation in reproductive hormones and gonadal histology. In intact male rats, numerous studies show decrements in testosterone (Cicero et al., 1978, 1979; Rivier and Vale, 1983; Rivier et al., 1984; Salonen and Huhtaniemi, 1990; Adams and Cicero, 1991; Ida et al., 1992; Little et al., 1992; Gonzalez-Reimers et al., 1994). These alcohol-evoked decreases in testosterone could result from actions at multiple sites of the hypothalamic-pituitary-gonadal (HPG) axis. At the gonad, decreased testosterone secretion could result from actions on steroid enzymes within the Leydig cells, from blunted responsiveness to luteinizing hormone (LH), or from suppressed pituitary secretion of LH. Inhibition of $\mathrm{LH}$ secretion could result from the effects of alcohol on the gonadotropes or from a lack of stimulation by hypothalamic LH-releasing hormone (LHRH). In this latter case, alcohol could directly inhibit the activity of LHRH neurons, or it could modulate afferent pathways. Although the

\footnotetext{
Received Nov. 14, 1996; revised Jan. 13, 1997; accepted Jan. 22, 1997.

This research was supported by National Institutes of Health Grant AA-06420 and a training grant to K.M.O. (NIAAA 07456), and the Foundation for Research. C.R. is a Foundation for Research investigator. We received excellent technical support from S. Johnson and T. Sagrado. We are also grateful to Drs. R. Benoit, G. Niswinder, J. Rivier, and W. Vale for providing reagents and to Dr. G. Erickson for advice on the analysis of ovarian morphology.

Correspondence should be addressed to Dr. Catherine Rivier, Clayton Foundation Lab, Salk Institute for Biological Studies, 10010 North Torrey Pines Road, La Jolla, CA 92037.

Copyright (C) 1997 Society for Neuroscience 0270-6474/97/172595-10\$05.00/0
}

majority of in vivo studies report that alcohol decreases LH (Cicero et al., 1978, 1979; Dees et al., 1983; Salonen and Huhtaniemi, 1990; Adams and Cicero, 1991; Little et al., 1992), others document increased (Salonen et al., 1992) or unchanged (Ida et al., 1992) levels during intoxication. In vitro studies have failed to clarify the primary site of the actions of alcohol on male reproduction, because effects have been described in isolated testicular tissue (Cobb et al., 1980; Van Thiel et al., 1981; Cicero and Bell, 1982; Santucci et al., 1983; Widenius, 1987; Akane et al., 1988; Orpana et al., 1990), in pituitary gonadotropes (Schade et al., 1983; Uddin et al., 1994), and in hypothalamic preparations (Emanuele et al., 1990; Inukai et al., 1993; Canteros et al., 1995).

In females, unraveling the effects of alcohol on reproduction is complicated by the cyclic nature of hormone secretion. Work from several laboratories has suggested that alcohol inhibits the LH surge. Restriction of female rats to a diet containing alcohol evokes persistent diestrus (Rettori et al., 1987), and administration of alcohol by injection on diestrous day 2 prevents the proestrous surge the following day (Marcó et al., 1984; Alfonso et al., 1993a). However, ovariectomized (OVX) rats in which a surge was evoked by estradiol $\left(\mathrm{E}_{2}\right)$ administration had a normal LH surge despite daily feeding of an alcohol-containing diet (Emanuele et al., 1986). In OVX rats not supplemented with $\mathrm{E}_{2}$ and characterized by constantly elevated levels of LH, alcohol decreases (Dees and Kozlowski, 1984; Dees et al., 1985; Rivier et al., 1992) or does not affect (Subramanian et al., 1990) levels of this hormone. In contrast, alcohol administration to diestrous females characterized by low LH concentrations increases LH (Lafuente et al., 1994). Similar to the literature regarding males, in vitro data 
do not reveal the primary site of the action of alcohol, because effects have been described in isolated median emini (Hiney and Dees, 1991), anterior pituitary glands (Alfonso et al., 1993b), and ovarian granulosa cells (Nishimori et al., 1993; Wimalasena et al., 1993; McKenzie et al., 1995).

Because the critical endocrine event in the female reproductive cycle is the surge of gonadotropins, which causes ovulation, we chose to study the effects of acute $(1 \mathrm{~d})$ alcohol exposure on the proestrous surge of $\mathrm{LH}$ in the female rat. Here we report that alcohol exposure on the day of proestrus prevents the surges of LH and LHRH and perturbs surge-related rhythms of $E_{2}$ and progesterone $\left(\mathrm{P}_{4}\right)$. Because the proestrous surge is generated by the interplay of ovarian and hypothalamic hormones (Kalra, 1993), we also present data from OVX-E $\mathrm{E}_{2}$ and adrenalectomized (ADX) females to discount a role for peripheral steroids in the inhibitory effect of alcohol on the LH surge. Last, we show that administration of LHRH restores the surge and ovulation, supporting the conclusion that the primary effect of alcohol on the proestrous surge of gonadotropins is exerted at the level of the CNS.

\section{MATERIALS AND METHODS}

\section{Animals}

Adult female rats $55 \mathrm{~d}$ of age or older were purchased from Harlan Sprague Dawley (Indianapolis, IN) and maintained on a $12 \mathrm{hr}$ light/dark cycle (lights on at 6 A.M.). Food and water were available continuously. The day after animals arrived in the laboratory, estrous cycles were synchronized (see below), and animals were housed individually in hanging metal cages. Indwelling cannulae (either intravenous or intraperitoneal, or both) were inserted under halothane anesthesia (Levine et al., 1994; Ogilvie and Rivier, 1996) on diestrous day 1 (i.e., 2 d before experimentation). On the day of an experiment, animals were removed to a soundproof room and housed in opaque buckets with cannulae connected so that the animals could be injected and bled without being handled. All protocols were approved by the Salk Institute Institutional Animal Care and Use Committee. All chemicals were purchased from Sigma (St. Louis, MO), unless noted otherwise.

Experiment 1: Effect of alcohol administered on proestrus on reproductive hormone secretion and ovulation. Proestrous females were injected with alcohol or vehicle at 8 A.M. and 12 P.M. on proestrus. Half of the animals in each group were bled at hourly intervals that afternoon. The remaining animals were returned to their buckets the following morning and bled at hourly intervals on the afternoon of predicted estrus. $\mathrm{LH}, \mathrm{E}_{2}$, and $\mathrm{P}_{4}$ were measured in each sample as described below. Animals were killed by $\mathrm{CO}_{2}$ asphyxiation at 9 A.M. the morning after they were bled. Oviducts were examined for the presence of ova.

Experiment 2: Effect of alcohol administered on proestrus on ovarian morphology. Proestrous females were injected with alcohol or vehicle at 8 A.M. and 12 P.M. on proestrus. Half of the animals in each group were perfused transcardially with $4 \%$ paraformaldehyde to preserve ovarian tissue at 9-10 A.M. on the morning of predicted estrus, and the remaining animals were killed in the same manner $2 \mathrm{~d}$ after drug treatment, on predicted diestrous day 1 . Ovaries were removed, debrided, and stored in $4 \%$ paraformaldehyde and then in $70 \%$ alcohol until they were embedded in paraffin and processed for histological examination (see below).

Experiment 3: Effect of alcohol on activation of LHRH neurons on the afternoon of proestrus. Proestrous female rats were injected with alcohol or vehicle at 8 A.M. and 12 P.M. Animals were killed by transcardial perfusion of $4 \%$ paraformaldehyde between 5 and 6 P.M. Brains were processed for detection of Fos and LHRH proteins by immunocytochemistry (see below) in the same sections. Expression of both Fos and LHRH in the same neuron was taken as an indication of activation of that neuron during the afternoon of proestrus (Sagar et al., 1988; Lee et al., 1990).

Experiment 4: Effect of alcohol on LHRH secretion on the day of proestrus. Push-pull cannulation of the anterior pituitary was performed on the day of proestrus in females that were noninjected, injected with vehicle, or injected with alcohol at 8 A.M. and 12 P.M. Some animals were sampled during several estrous cycles so that they could serve as their own control. We chose to use push-pull cannulation rather than microdialysis because in vitro testing showed that the exposure of com- mercially available microdialysis probes (polycarbonate and polyether sulfone) to $1 \%$ alcohol resulted in a decrease in recovery of radioactive LHRH across the membrane. We also chose to sample the anterior pituitary because of the greater likelihood of correct placement as well as the importance of sampling the integrated LHRH signal to the gonadotropes (Levine and Powell, 1989; Grattan et al., 1995).

Experiment 5: Effect of alcohol on the LH surge in OVX females implanted with $E_{2}\left(O V X-E_{2}\right)$. To test the hypothesis that alcohol suppresses the $\mathrm{LH}$ surge by preventing $\mathrm{E}_{2}$ secretion and consequent positive feedback, females were ovariectomized and given $E_{2}$ implants $9 \mathrm{~d}$ before experimentation, a paradigm that reliably results in daily afternoon surges of LH (DePaolo and Barraclough, 1979b; Weiland et al., 1992). Implants were made of SILASTIC tubing (inner diameter, $20 \times 1.57 \mathrm{~mm}$; Dow Corning, Midland, MI) filled with $\mathrm{E}_{2}$ benzoate (E9000) suspended in peanut oil $(180 \mu \mathrm{g} / \mathrm{ml})$. This type of implant produces physiological levels of $\mathrm{E}_{2}$ (Weiland et al., 1992). Control animals were intact proestrous females. On the day of the experiment, animals were injected with vehicle or alcohol at 8 A.M. and 12 P.M. Blood samples were collected every hour from 12 P.M. to 5 P.M. and assayed for LH content.

Experiment 6: Effect of alcohol on the proestrous LH surge and ovulation in $A D X$ female rats. To determine whether adrenal secretion of either $\mathrm{P}_{4}$ or corticosterone in response to alcohol administration had a role in suppression of the LH surge and ovulation, female rats were adrenalectomized the day after estrous cycles were synchronized. Control animals were intact proestrous rats. Seven days after surgery on the afternoon of proestrus, animals were injected with alcohol or vehicle at 8 A.M. and 12 P.M. and bled for the measurement of $\mathrm{LH}$ at hourly intervals during the afternoon. At 9 A.M. the next day, animals were killed by $\mathrm{CO}_{2}$ asphyxiation, and the oviducts were examined for ova.

Experiment 7: Effect of LHRH administration on secretion of $\mathrm{LH}$ and ovulation in animals treated with alcohol. To rule out the anterior pituitary and/or ovary as the primary site(s) of the inhibitory action of alcohol, we tested whether secretion of $\mathrm{LH}$ and ovulation would be restored by mimicking hypothalamic secretion of LHRH. Intact proestrous rats were injected with alcohol or vehicle at 8 A.M. and 12 P.M. Half of the alcohol-treated rats were also injected with LHRH at half-hour intervals from 1 P.M. to 4:30 P.M. (150 ng/pulse, i.v.; kindly provided by Dr. J. Rivier, La Jolla, CA), a paradigm used successfully to induce an LH surge in pentobarbital-blocked rats (Bauer-Dantoin et al., 1991). Animals were killed the following morning at 9 A.M., and the presence of ova in the oviducts was determined.

\section{Estrous cycle synchronization}

The estrous cycle rhythm was synchronized in each cohort of female rats by subcutaneous injection of the LHRH analog D-Trp ${ }^{6}-$ Pro $^{9}-$ Net-GnRH at 9 A.M. and 2 P.M. $(2 \mu \mathrm{g} /$ animal/injection; kindly provided by Dr. J. Rivier). Typically, $75 \%$ of female rats subject to this treatment will exhibit a proestrous smear $8 \mathrm{~d}$ later. Vaginal smears were taken daily, and only those females that were synchronized and had regular $4 \mathrm{~d}$ estrous cycles were used.

\section{Alcohol treatment}

Alcohol was given intraperitoneally through an indwelling cannula, at a dose of $3 \mathrm{gm} / \mathrm{kg}$ body weight (BW) in a solution of saline containing $5 \%$ lidocaine. Lidocaine was administered to minimize discomfort caused by expansion of the abdomen. The final concentration of alcohol was always $<20 \%$ to prevent damage to peritoneal epithelia. All animals within an experiment received the same injection volume, including controls, which were injected with the saline/lidocaine vehicle $(0 \mathrm{gm} / \mathrm{kg} \mathrm{BW})$. Because of the large volume administered, injections were given over a period of 2-3 min. A single injection of $3 \mathrm{gm} / \mathrm{kg} \mathrm{BW}$ alcohol results in blood alcohol levels (BALs) of $313 \pm 29 \mathrm{mg} \%$ within $15 \mathrm{~min}$, which diminish to near 0 by $3 \mathrm{hr}$ post-injection (K. Ogilvie and C. Rivier, unpublished observations). Animals subject to this dosing regimen were impaired for the duration of the afternoon.

\section{Histological examination of the ovaries}

Ovaries were embedded in paraffin and sectioned at $7 \mu \mathrm{m}$. Serial sections were mounted on gelatin-coated slides, baked $30 \mathrm{~min}$ at $55^{\circ} \mathrm{C}$, and stained with hematoxylin and eosin. Follicles $>500 \mu \mathrm{m}$ in diameter were counted and graded as to whether the granulosa cells were luteinized or appeared apoptotic. To avoid duplicate counting, follicles were classified only in sections where the nucleus of the ovum could be observed. 


\section{Push-pull perfusion}

Animals were implanted stereotaxically with 22-gauge guide cannulae (11 mm long; C312ICP, Plastics One, Roanoke, VA) while they were anesthetized with $0.5 \mathrm{ml}$ of an anesthesia cocktail (acepromazine, $2 \mathrm{mg} / \mathrm{ml}$; xylazine $10 \mathrm{mg} / \mathrm{ml}$; and ketamine $50 \mathrm{mg} / \mathrm{ml}$ ). The tip of the guide cannulae was directed toward the anterior pituitary using coordinates derived from the atlas of Paxinos and Watson (1986) and were as follows: nose bar set at $-3.3 \mathrm{~mm}, 5.5 \mathrm{~mm}$ posterior and $1.5 \mathrm{~mm}$ lateral to bregma, $1.0 \mathrm{~mm}$ dorsal to the surface of the sella turcica. Animals were allowed at least $10 \mathrm{~d}$ to recover before the first push-pull perfusion session, and the estrous cycle stage was confirmed with daily vaginal smears. At 8 A.M. on the day of proestrus, an animal was removed to a soundproof room and given the first injection. At approximately 11 A.M., the dummy cannula was removed and a push-pull cannula (C313DC, Plastics One) was inserted into the guide. Artificial cerebral sinus fluid (aCSF) $(145 \mathrm{mmol}$ $\mathrm{NaCl}, 3.3 \mathrm{mmol} \mathrm{KCl}, 1.3 \mathrm{mmol} \mathrm{CaCl}_{2}, 1 \mathrm{mmol} \mathrm{MgCl}_{2}, 0.5 \% \mathrm{BSA}$, sterile-filtered) was perfused through the cannula and collected in $10 \mathrm{~min}$ fractions $(\sim 125 \mu \mathrm{l})$ into plastic microcentrifuge tubes containing a protease inhibitor (aprotonin). Fractions were collected from each animal, encompassing the entire afternoon of proestrus. Perfusates were snapfrozen on dry ice, stored overnight at $-20^{\circ} \mathrm{C}$, lyophilized, and returned to $-20^{\circ} \mathrm{C}$ until assayed for LHRH as described below.

\section{Immunocytochemistry}

The day after brains were collected, they were sectioned frozen at $30 \mu \mathrm{m}$ and stored in a cryoprotectant solution (50\% $0.1 \mathrm{~m} \mathrm{PBS,} \mathrm{30 \%} \mathrm{ethylene}$ glycol, and $20 \%$ glycerol) at $-20^{\circ} \mathrm{C}$ until they were subjected to immunocytochemistry for both Fos and LHRH in free-floating sections (every fifth). Nonspecific binding was blocked by treatment with normal goat serum (1:25) followed by incubation with primary antiserum (1:40,000 Ab5 generated to cfos, Oncogene Sciences; 1:50,000 LR1 generated to LHRH, kindly provided by Dr. R. Benoit, Montreal, Quebec) for $36 \mathrm{hr}$ at $4^{\circ} \mathrm{C}$. LR1 recognizes intact LHRH and precursor peptide in fixed brain tissue (Silverman et al., 1990). After several washes with KPBS $/ 0.25 \%$ BSA/0.02\% Triton X-100, sections were incubated with biotinylated antirabbit gamma globulin for $1 \mathrm{hr}$, washed, and incubated with horseradish peroxidase-avidin complex for $30 \mathrm{~min}$. Color product was formed by incubating with diaminobenzidine and hydrogen peroxide (LHRH staining; brown product), whereas nickel intensification was used for Fos staining (black product). Sections were initially stained for Fos, followed immediately by processing to detect cells containing LHRH. Sections were mounted on poly-L-lysine-coated slides, vacuum-dried overnight, dehydrated through an alcohol series, cleared in xylenes, and coverslipped with DPX (13512, Electron Microscopy Sciences). In each section through the preoptic area (POA) [i.e., seven sections/brain corresponding to anterior-posterior coordinates 0.10 through $-0.83 \mathrm{~mm}$ (Paxinos and Watson, 1986)], the number of LHRH neurons and the subset that was also labeled for Fos were counted.

\section{Ovariectomy and adrenalectomy}

Ovaries or adrenal glands were removed under halothane anesthesia using a dorsal approach. After a midline incision had been made in the skin, the body wall was pierced superficially to the position of the organ to be removed. To prevent excessive bleeding, ovaries were removed after the uterine horn was tied off. After removal of the gland, the body wall was suture-closed with silk. In OVX animals, an $\mathrm{E}_{2}$ implant was placed subcutaneously before closure of the skin with wound clips. Adrenalectomy was confirmed by the absence of measurable corticosterone in samples taken at 12 P.M. on the day of the experiment.

\section{Hormone measurements}

Blood was collected into chilled polystyrene tubes containing EDTA ( 0.6 $\mathrm{mg} / 500 \mu \mathrm{l}$ whole blood) and centrifuged. The resulting plasma was aspirated and stored frozen in plastic tubes at $-20^{\circ} \mathrm{C}$ until assay for $\mathrm{LH}$, $\mathrm{E}_{2}$, or $\mathrm{P}_{4}$.

LH was assayed in duplicate by double-antibody radioimmunoassay (RIA) using standard (RP-3) provided by the National Institute of Diabetes and Digestive and Kidney Diseases and primary antibody (\#15) provided by Dr. G. Niswender (Fort Collins, CO). Precipitation of antibody-bound LH was accomplished with the addition of anti-rabbit gamma globulin raised in sheep (kindly provided by Dr. W. Vale, La Jolla, CA) followed by a wash $(0.5 \%$ Tween 20 and $5 \%$ polyethylene glycol) and centrifugation. The sensitivity of this assay is $0.06 \mathrm{ng} / \mathrm{ml}$, and the coefficient of variation, determined using plasma pools, never exceeded $16 \%$.

$\mathrm{E}_{2}$ and $\mathrm{P}_{4}$ were each measured in $50 \mu \mathrm{l}$ of plasma using a kit based on antibody-coated tube methodology (DPC, Los Angeles, CA). The sensitivity of these assays is $20 \mathrm{pg} / \mathrm{ml}$ for $\mathrm{E}_{2}$ and $0.1 \mathrm{ng} / \mathrm{ml}$ for $\mathrm{P}_{4}$. All samples were assayed at the same time.

Lyophilized push-pull perfusate samples were resuspended in aCSF before being assayed in duplicate by double-antibody RIA for LHRH content. The primary antibody used was LR1 at a final concentration of 1:500,000 (20-6-79; kindly provided by Dr. R. Benoit, Montreal, Quebec, Canada). Sheep anti-rabbit gamma globulin was used to precipitate bound hormone. This assay has a sensitivity of $0.6 \mathrm{pg} / \mathrm{sample}$ and a coefficient of variation, determined with pools of median eminence extracts, of $<12 \%$.

\section{Statistical analysis}

Plasma hormone data were analyzed using a repeated measures ANOVA, with treatment and predicted day of estrous cycle as the variables. Ovulation data are reported in the figure legends as percentages of the total number of animals examined. The immunocytochemistry data (ratio of double-labeled cells to total number of LHRH-positive cells) were subject to a repeated-measures ANOVA (sections of brain). Data on ovarian morphology were subjected to a two-way ANOVA, with drug treatment and predicted day of the cycle as the variables. When the ANOVA procedure detected an effect of one of the variables or the interaction of two variables, the least squares means post hoc test was used to determine which groups differed.

\section{RESULTS}

\section{Experiment 1: Alcohol administered on proestrus blocks the surge of $\mathrm{LH}$, diminishes secretion of $\mathrm{E}_{2}$, increases secretion of $\mathbf{P}_{\mathbf{4}}$, and prevents ovulation}

As expected, the pattern of plasma hormone levels in female rats differed between the afternoons of proestrus and estrus [ $\mathrm{LH}$, day of cycle, $p=0.0479$; repeated measure $(\mathrm{rm})$ of $\mathrm{LH} \times$ day of cycle, $p=0.0194 ; \mathrm{E}_{2}, \mathrm{rm}$ of $\mathrm{E}_{2} \times$ day of cycle, $p=0.0217 ; \mathrm{P}_{4}$, day of cycle, $p=0.0051$; rm of $\mathrm{P}_{4} \times$ day of cycle, $p=0.0038$ (Fig. 1 )]. In addition, the rm of each hormone also reached or neared significance, indicating that each hormone was changing over time (LH, $\left.p=0.0537 ; \mathrm{E}_{2}, p=0.0333 ; \mathrm{P}_{4}, p=0.0195\right)$. Alcohol affected the levels of all three hormones $(\mathrm{LH}, \mathrm{rm} \times \mathrm{drug}, p=0.0537$; $\mathrm{rm} \times$ drug $\times$ day of cycle, $p=0.0300 ; \mathrm{E}_{2}$, drug $\times$ day of cycle, $p=$ $0.0612 ; \mathrm{P}_{4}$, drug, $p=0.0234, \mathrm{rm} \times$ drug, $\left.p=0.0038\right)$. Post hoc testing shows that animals treated with vehicle were characterized by a surge of LH on the afternoon of proestrus. Alcohol abolished this surge and slightly but significantly decreased plasma $\mathrm{E}_{2}(p=$ $0.0220)$ while elevating plasma $\mathrm{P}_{4}(p=0.0044)$. Importantly, no ova were observed on the morning of predicted estrus in animals treated with alcohol on proestrus.

\section{Experiment 2: Alcohol administered on proestrus results in luteinized unruptured follicles}

Histological examination of the ovaries indicated the presence of numerous large follicles in animals that had been treated with alcohol on the day of proestrus (treatment, $p=0.0002$; summarized in Table 1; representative sections in Fig. 2). Many of the large follicles observed in these animals were luteinized (treatment, $p<0.0001$ ) by the morning after alcohol treatment, and many of the large follicles had apoptotic cells $2 \mathrm{~d}$ after alcohol treatment (treatment, $p=0.0454$; treatment $\times$ day of cycle, $p=$ $0,0454)$. These data confirm that ovulation did not occur in female rats treated with alcohol on the day of proestrus.

\section{Experiment 3: Alcohol reduces activation of LHRH neurons on the afternoon of proestrus}

Alcohol did not alter the number of LHRH neurons counted in the diagonal band of Broca and POA (vehicle, $n=180.13 \pm$ 
Figure 1. Alcohol administered on proestrus blocks the surge of $\mathrm{LH}$, diminishes secretion of $\mathrm{E}_{2}$, increases secretion of $\mathrm{P}_{4}$, and blocks ovulation. Left panels: $\mathrm{LH}, \mathrm{E}_{2}$, and $\mathrm{P}_{4}$ concentrations in plasma of proestrous rats injected with vehicle or alcohol at 8 A.M. and 12 P.M. on proestrus. Right panels: $\mathrm{LH}, \mathrm{E}_{2}$, and $\mathrm{P}_{4}$ concentrations during the afternoon of predicted estrus in rats injected with vehicle or alcohol at 8 A.M. and 12 P.M. on proestrus. Each point represents the mean \pm SEM of 5-14 rats. *, Treatment group is significantly different from both alcohol-treated groups and vehicle-treated animals on estrus $(p<0.05$; least squares means post hoc test). \#, Treatment group is significantly different from both vehicletreated groups and alcohol-treated animals on predicted estrus $(p<0.05)$. Ova were observed in the oviducts of $72.7 \%$ of the vehicle-treated animals bled on the afternoon of proestrus and killed the next morning. Ova were not observed in females from other treatment groups. Other statistical details are given in the results.
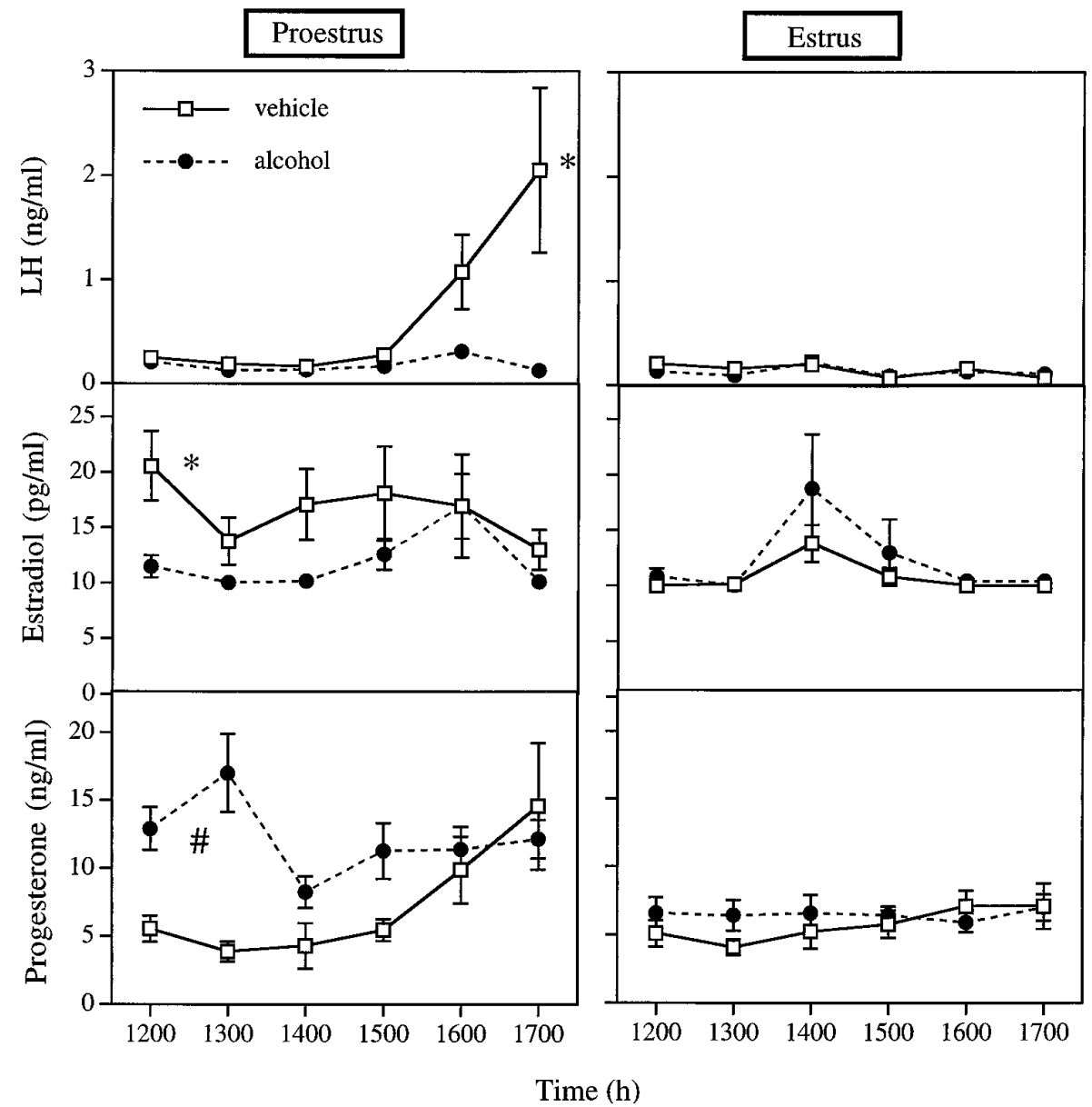

Time (h)

\begin{tabular}{|c|c|c|c|c|}
\hline $\begin{array}{l}\text { Predicted } \\
\text { day of } \\
\text { estrous cycle }\end{array}$ & $\begin{array}{l}\text { Treatment } \\
\text { on } \\
\text { proestrus }\end{array}$ & $\begin{array}{l}\text { Follicles } \\
>500 \mu \mathrm{m} \\
\text { diameter }\end{array}$ & $\begin{array}{l}\text { Luteinized } \\
\text { follicles }\end{array}$ & $\begin{array}{l}\text { Follicles with } \\
\text { apoptotic } \\
\text { cells }\end{array}$ \\
\hline Estrus & Vehicle & $1.8 \pm 0.5^{a}$ & $0.5 \pm 0.3^{a}$ & $0.0 \pm 0.0^{a}$ \\
\hline Estrus & Alcohol & $6.8 \pm 0.9^{b}$ & $5.8 \pm 0.2^{b}$ & $0.0 \pm 0.0^{a}$ \\
\hline Diestrus & Vehicle & $2.8 \pm 0.5^{a}$ & $0.8 \pm 0.2^{a}$ & $0.2 \pm 0.2^{b}$ \\
\hline Diestrus & Alcohol & $8.0 \pm 1.6^{b}$ & $6.2 \pm 0.9^{b}$ & $3.8 \pm 1.5^{c}$ \\
\hline
\end{tabular}

Within a column, groups that do not share a letter differ significantly $(p<0.05$, least-squares means test).

37.82; alcohol, $n=164.41 \pm 17.56 ; p=0.6991$ ) or the number of LHRH neurons in the brain. This is in general agreement with data published previously (Silverman et al., 1990). In the POA, in which most double-labeled LHRH neurons were observed, proestrous females treated with vehicle had a sum average of $32.7 \%$ of LHRH neurons stained for Fos, a result similar to that reported by others (Lee et al., 1990; Rivest and Rivier, 1993). In proestrous females treated with alcohol, however, the percentage of LHRH neurons that also stained for Fos was significantly reduced (drug, $p=0.0297$ ) (Fig. 3).

\section{Experiment 4: Alcohol administration on the day of proestrus reduces LHRH secretion}

Figure 4 illustrates representative animals with alternate vehicle and alcohol treatments. Surges of LHRH occurred during control sessions regardless of the order of treatments. The timing of the surge of LHRH release was similar to that reported previously for proestrous female rats, occurring within $4 \mathrm{hr}$ of lights off (Levine and Ramirez, 1982). Similarly, levels of LHRH measured early in the afternoon were within the range of values reported within the anterior pituitary of intact males (Levine and Powell, 1989; Grattan et al., 1995). In animals injected with alcohol at 8 A.M. and 12 P.M., no increases in LHRH (overall mean $=2.64 \pm 0.15 \mathrm{pg}$ / sample vs $10.65 \pm 1.63 \mathrm{pg} / \mathrm{sample}$ for vehicle-treated animals; $p<$ 0.0001) occurred, despite the fact that this hormone was still measurable, indicating that alcohol prevented the surge of LHRH in these animals. We also noted large variability in the amount of LHRH measured in control animals. It is unclear from our data whether this is attributable to small anatomical differences in cannula placement, increased perfusion efficiency in some animals, or inter-individual variation in the amount of LHRH secreted. Other laboratories, however, have reported a wide range of LHRH concentrations within the portal plasma of female rats (Sarkar et al., 1976; Sarkar and Minami, 1995) as well as different individual patterns of secretion on the afternoon of proestrus (Levine and Ramirez, 1982).

\section{Experiment 5: Alcohol inhibits the LH surge of OVX-E ${ }_{2}$ females}

In this experiment and those to follow, there was a significant effect of the repeated measure of LH ( $p<0.0001$ in all cases), indicating surges during the afternoon. Alcohol administration also affected hormone levels (drug, $p=0.0073$; rm $\times$ drug, $p=$ $0.0114)$, resulting in diminished levels of $\mathrm{LH}$ in both intact and OVX-E 2 animals (Fig. 5). OVX-E ${ }_{2}$ rats treated with alcohol were 


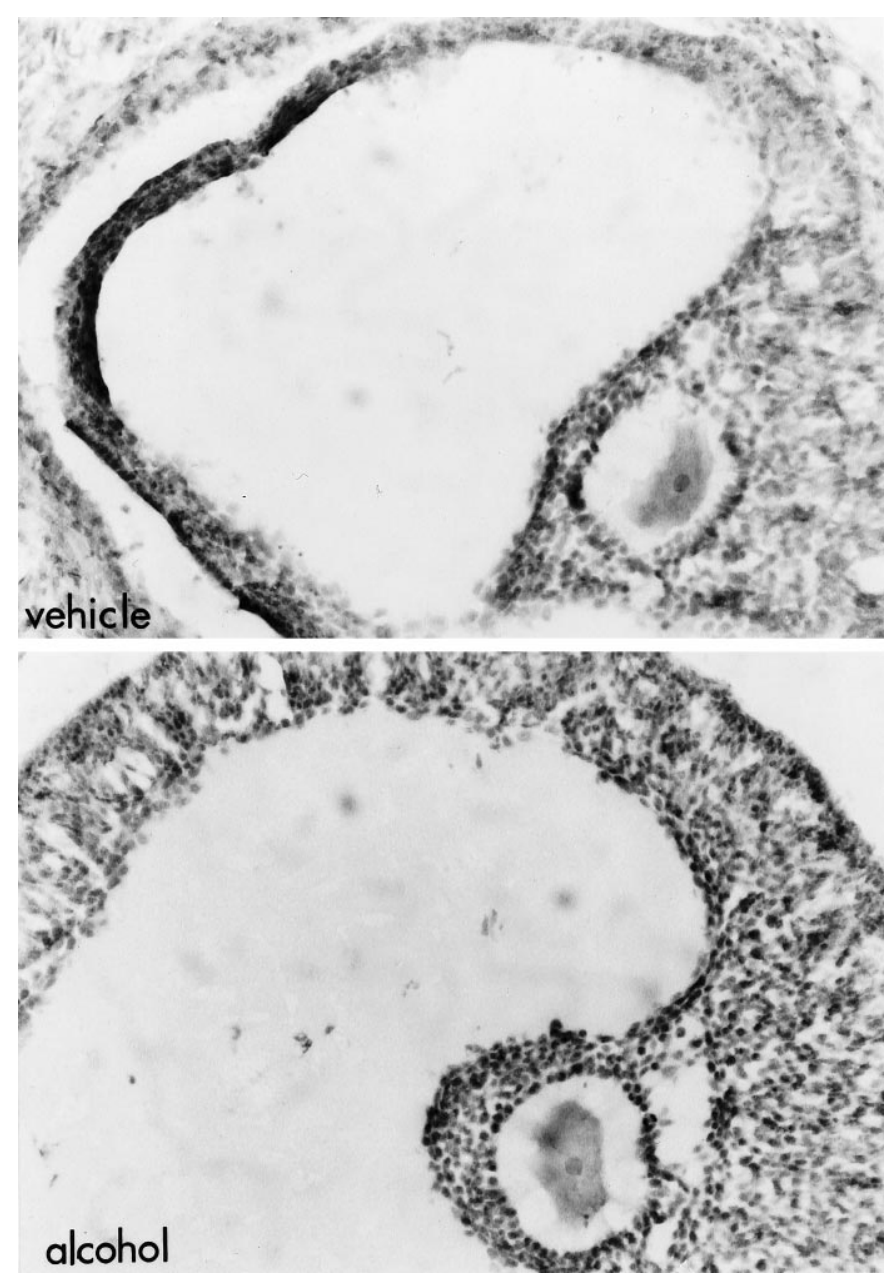

Figure 2. Alcohol administered on proestrus results in luteinized unruptured follicle. Photomicrographs of ovarian follicles in animals killed on estrus after treatment with vehicle (top) or alcohol (bottom) at 8 A.M. and 12 P.M. on proestrus. Note that the largest follicles present in control females were smaller and less numerous than those observed in animals exposed to alcohol on proestrus. The large follicles present in alcoholtreated animals were characterized by luteinization (note the greater number of layers as well as the increase in the ratio of cytoplasm to nucleus) of the granulosa layers. Morphological findings, summarized in Table 1, confirm that animals do not ovulate after injection with alcohol on the afternoon of proestrus. Magnification, $300 \times$.

different from both vehicle-injected groups $(p<0.02$, least squares means post hoc test), indicating that alcohol was capable of suppressing LH secretion in the absence of the ovary.

\section{Experiment 6: Alcohol blocks the proestrous LH surge and ovulation in ADX female rats}

In $\mathrm{ADX}$ animals, alcohol administration blocked the preovulatory surge of LH (Fig. 6) (drug, $p=0.0015$; rm $\times$ drug, $p<0.0001$ ), with vehicle-treated animals differing from alcohol-treated animals regardless of surgical manipulation $(p<0.05$, least squares means post hoc test). These results discount a role of the adrenal in the mechanism by which alcohol suppresses the generation of the LH surge.

\section{Experiment 7: LHRH administration restores the surge of LH and ovulation in animals treated with alcohol}

Alcohol administration to intact animals again resulted in suppression of the preovulatory surge of LH (Fig. 7). When exoge- nous LHRH was administered in pulses throughout the afternoon, however, all animals showed robust secretion of LH, and ovulation by the next morning (treatment, $p<0.0001$; $\mathrm{rm} \times$ treatment, $p<0.0001$ ). This suggests that both the pituitary and the ovary can show normal activity, despite the presence of alcohol, if the correct hypothalamic signal is imitated.

\section{DISCUSSION}

Our data firmly support the hypothesis that in the female rat, alcohol exerts its inhibition of the reproductive axis primarily at the level of the CNS. First, we have presented data that indicate an absence of hypothalamic activation in proestrous animals injected with alcohol. Animals treated in this manner lacked an LHRH surge (Fig. 4) and did not express Fos in LHRH neurons (Fig. 3), which showed that these neurons were not activated. Furthermore, we have provided evidence that neither the ovary nor the adrenal gland are primarily responsible for the lack of an LH surge after alcohol administration. Although one possibility was that alcohol might act by reducing ovarian secretion of $\mathrm{E}_{2}$ (Fig. 1) and the subsequent positive feedback at the hypothalamic level, the results from OVX-E $\mathrm{E}_{2}$ females showed clearly that alcohol was able to prevent an LH surge in the absence of a reduction in $\mathrm{E}_{2}$ concentrations (Fig. 5). It had also been suggested that adrenal secretion of glucocorticoids, which are released by alcohol exposure (Rivier, 1993; Ogilvie and Rivier, 1996) or $\mathrm{P}_{4}$ (Fig. 1), might inhibit the generation of the proestrous surge. This idea is refuted, however, by the efficacy with which alcohol blocked the LH surge in ADX animals (Fig. 6). Last, the effects of alcohol were overcome by administration of exogenous LHRH, suggesting that pituitary secretion of $\mathrm{LH}$ as well as ovulation are possible during alcohol exposure and will proceed if the hypothalamic signal is mimicked (Fig. 7).

Many investigations performed in male and female rodents concur that the hypothalamus is the primary site of the actions of alcohol. For instance, in anesthetized castrate males, secretion of LHRH to the portal circulation is decreased by alcohol injection (Ching et al., 1988). Similarly, intact male rats given an alcoholcontaining diet for 5 weeks are characterized by decreases in LH, follicle-stimulating hormone, and testosterone levels, although pituitary expression of receptors for LHRH and synthesis of the gonadotropins are not affected (Salonen and Huhtaniemi, 1990). Studies that investigated the responsiveness of the gonadotropes to LHRH stimulation found no effect of acute or chronic alcohol intoxication (Cicero et al., 1982; Rivier and Vale, 1983; Dees et al., 1985; Rivier et al., 1992). Also, LHRH content in the median eminence increases during chronic alcohol exposure, implying that LHRH release is impaired (Dees et al., 1983). In vitro, norepinephrine-evoked LHRH release from the median eminence of prepubertal female rats is blocked by alcohol (Hiney and Dees, 1991), as is nitric oxide-evoked release (Canteros et al., 1995).

On the other hand, some data conflict with our conclusion that the CNS is the site of the inhibitory actions of ethanol. For example, alcohol administration has been associated with increased or unchanged secretion of LH in both genders (see introductory remarks for references), whereas one study reported that the LH surge evoked by acute $\mathrm{E}_{2}$ injection was not blocked in animals fed an alcohol diet (Emanuele et al., 1986). In these experiments, however, BALs may have been insufficient to significantly alter the activity of LHRH neurons. Another study showed that alcohol altered levels of LH mRNA (Emanuele et al., 1991). Although this latter effect could have occurred secondary to 

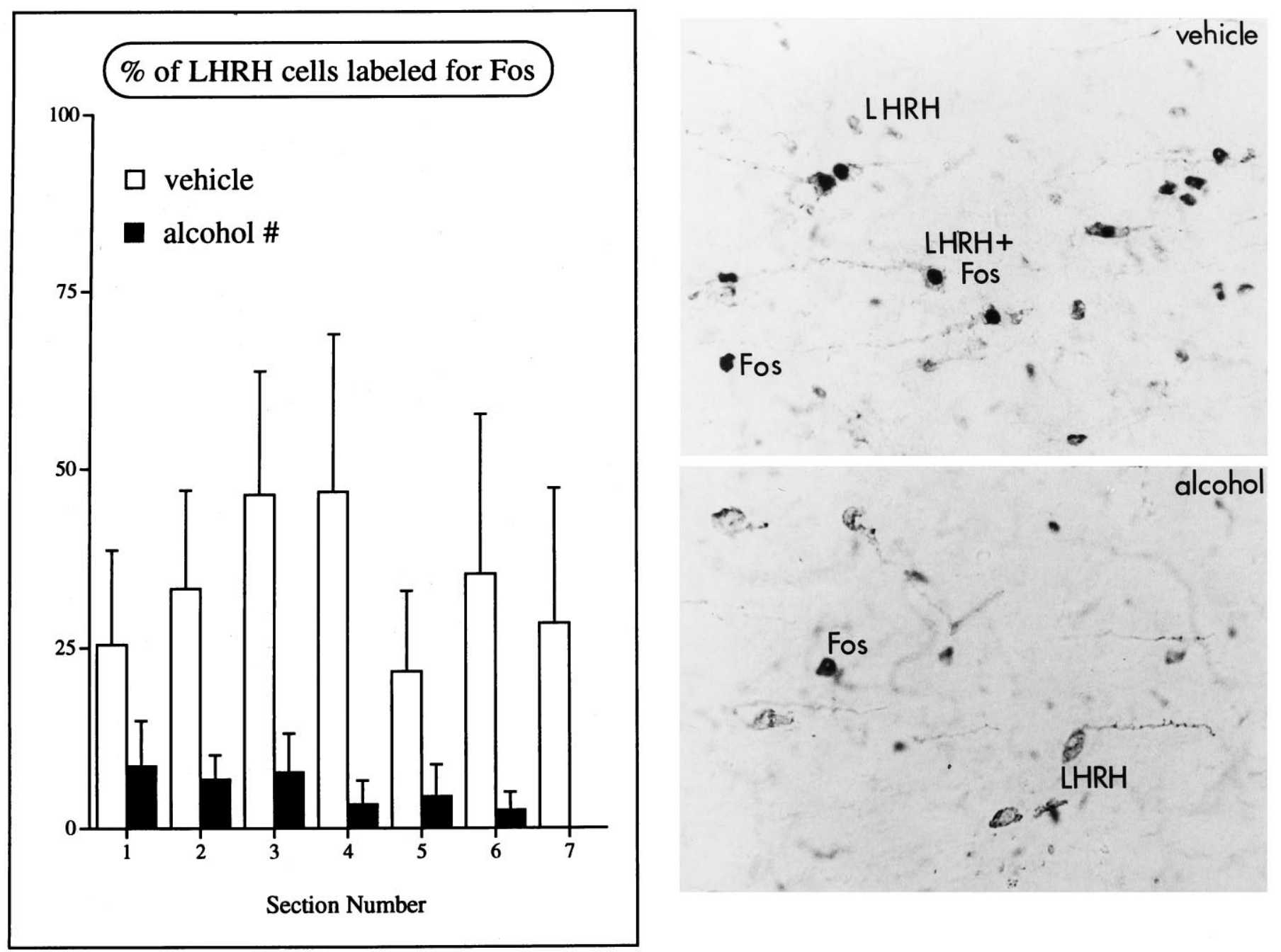

Figure 3. Alcohol reduces activation of LHRH neurons on the afternoon of proestrus. Left, Graph of the percentage of LHRH neurons that also express Fos on the afternoon of proestrus in the POA. Rostral-caudal level of the brain is indicated on the abscissa (see Materials and Methods), and each bar represents the mean \pm SEM of four to five animals; \# indicates that vehicle-treated animals have significantly more double-labeled cells than females treated with alcohol ( $p=0.0297$; repeated measures ANOVA). Right, Photomicrographs of the POA of proestrous animals injected with vehicle (top) or alcohol (bottom) at 8 A.M. and 12 P.M. and killed at 5-6 P.M. Cells containing LHRH have cytoplasmic staining, whereas labeling for Fos is darker and confined to the nuclei of cells. Note that although neurons stain for either Fos or LHRH after alcohol treatment, cells that are labeled for both antigens $(L H R H+F o s)$ are lacking in alcohol-treated female rats. Magnification, $1200 \times$.

changes in secretion of LHRH, these authors also showed that alcohol did not affect basal or $\mathrm{K}^{+}$-stimulated LHRH release from isolated rat hypothalami exposed to high concentrations of alcohol (Emanuele et al., 1990). Although the authors interpret their data to support an anterior pituitary site of the actions of alcohol, these data could also be interpreted to suggest that alcohol exerts its effects on afferents to LHRH neurons, rather than within the medial basal hypothalamus.

We show here that alcohol blocked the surge of LH for more than $24 \mathrm{hr}$. Other drugs that share the anesthetic-like effects of alcohol [i.e., pentobarbital (Everett and Sawyer, 1950; Kim et al., 1994) and ether (Kim et al., 1994)] reliably block the proestrous surge when they are given during the critical period, but do so only for exactly $24 \mathrm{hr}$. Several hypotheses may explain these results. First, alcohol could act at the level of the ovary, preventing $E_{2}$ secretion the day after alcohol exposure. In support of this hypothesis is the finding that exposure of cultured human or porcine granulosa cells to alcohol decreases LH-stimulated $\mathrm{E}_{2}$ secretion, in concert with declines in LH receptor binding (Nishimori et al., 1993; Wimalasena et al., 1993). The ovaries of our animals were characterized by follicles that had begun to luteinize by the next morning, and they contained apoptotic cells by the second morning after alcohol treatment; however, administration of LHRH to alcohol-treated animals restored the surge of $\mathrm{LH}$ and ovulation, arguing against an inability of the ovary to respond appropriately to this trophic signal. Furthermore, animals treated with pentobarbital also exhibit reduced levels of $\mathrm{E}_{2}$ but no impairment of the LH surge the following afternoon, and of ovulation (Butcher et al., 1974).

An alternate hypothesis to explain the lack of an LH surge the day after alcohol administration is that alcohol-evoked $\mathrm{P}_{4}$ secretion may be responsible for inhibiting the LH surge the next day (Kalra and Kalra, 1974; Kalra, 1975; Banks and Freeman, 1978; DePaolo and Barraclough, 1979a,b). This seems plausible given the high $\mathrm{P}_{4}$ levels measured in our female rats after alcohol exposure on proestrus, in contrast with those measured in 

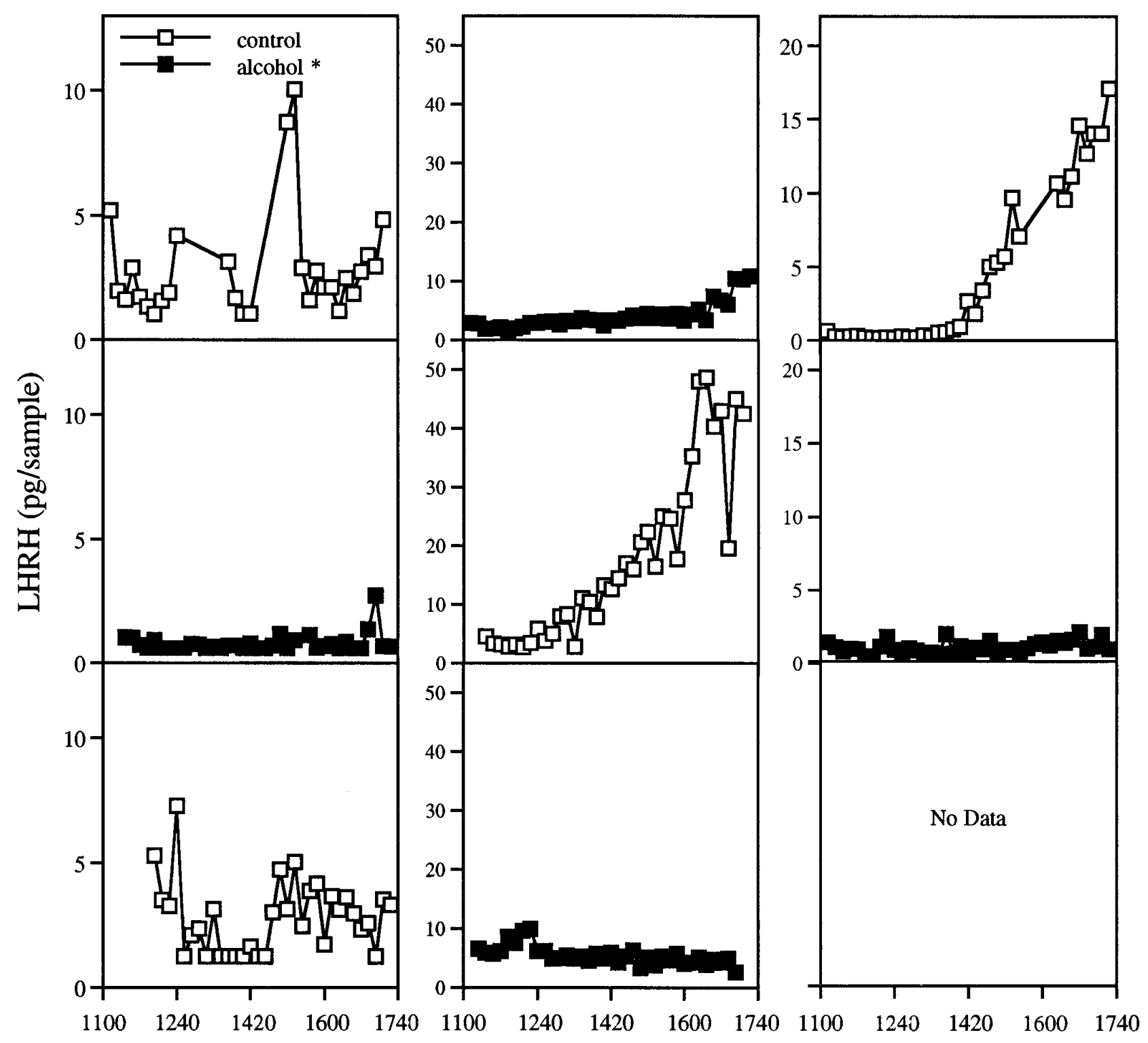

Time of Day (h)

Figure 4. Alcohol administration on the day of proestrus reduces LHRH secretion. LHRH secretion in three individual females studied on proestrus over several estrous cycles. Animals had surges of LHRH during control sessions but not after alcohol treatment. The order in which animals received treatments did not affect this result, indicating that alcohol does not permanently impair secretion of LHRH in these individuals.

pentobarbital-blocked rats (Butcher et al., 1974). This would suggest, however, that the gonadotropin surge and ovulation occurred $2 \mathrm{~d}$ after alcohol intoxication. Although this hypothesis has not been tested directly, there is a report that administration of alcohol to female rats on the afternoon of diestrous day 2 not only suspends the generation of the preovulatory surge the next day, but does so until $5 \mathrm{~d}$ after treatment [i.e., until the next proestrus (Alfonso et al., 1993a)]. Taken together, these data suggest that the delay in the generation of the proestrous surge is not attributable to ovarian insufficiency but may reside in the CNS where alcohol exerts its primary effect. It is possible, therefore, that alcohol acts on neuronal systems distinct from those on which other anesthetic drugs act.

Alcohol is known to act on several neuronal systems that might affect reproductive function. Chief among these is the HPA axis.
Acute administration of alcohol results in robust activation of adrenocorticotropin (ACTH) and corticosterone secretion, a phenomenon that requires corticotropin-releasing factor (CRF) stimulation of the anterior pituitary (Rivier et al., 1984). In males, these alcohol-evoked changes in hormone secretion are paralleled by activation of the paraventricular nucleus of the hypothalamus (PVN), as measured by expression of mRNAs for cfos (S. Lee and C. Rivier, unpublished observation), the immediate early gene nerve growth factor I-B (NGFI-B), CRF, and arginine vasopressin (Rivier and Lee, 1996; Ogilvie et al., 1997). Furthermore, CRF administration directly into the POA reduces the secretion of $\mathrm{LH}$ and LHRH in OVX females (Rivest et al., 1993). Similar to the effects of alcohol, restraint stress on the day of proestrus blocks the surge of LH (Roozendaal et al., 1995), suggesting that these two manipulations may rely on a similar mechanism. Thus, block- 
Figure 5. Alcohol inhibits the LH surge of OVX-E $E_{2}$ females. As expected, animals injected with vehicle had LH surges, and intact females ovulated $(71.4 \%)$. In contrast, animals injected with alcohol had reduced levels of $\mathrm{LH}$ whether they were intact (left, $40 \%$ ovulatory rate) or $\mathrm{OVX}-\mathrm{E}_{2}$ females (right). Each point represents the mean \pm SEM of seven to eight rats. \#, Alcohol-treated OVX-E $E_{2}$ animals differ significantly from vehicle-treated groups $(p<0.02$; least squares means post hoc test).
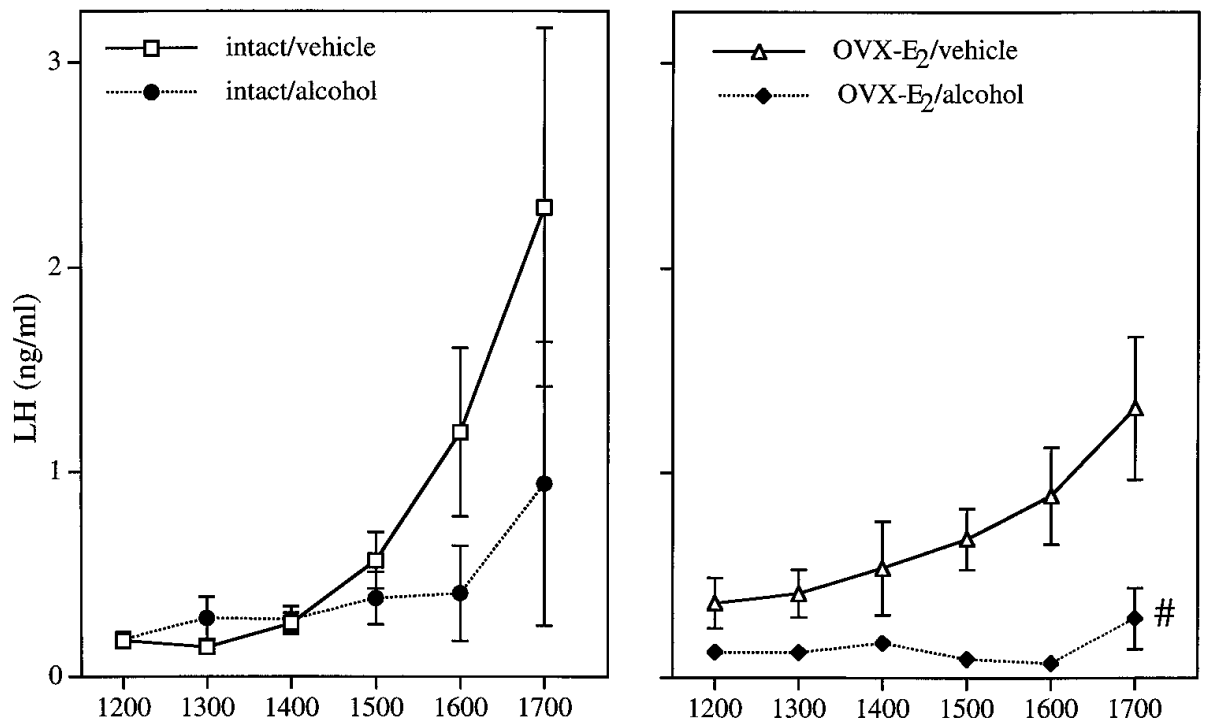

Time (h) ade of the proestrous surge of gonadotropins could depend on high circulating levels of HPA hormones or activation of CRF neuronal systems within the brain; however, ablation of the PVN does not impair alcohol-evoked decreases in LH (Rivier et al., 1992), although secretion of ACTH is blunted (Rivest and Rivier, 1994; Ogilvie et al., 1997). Furthermore, we observed that adrenalectomy does not prevent alcohol administration from blocking the preovulatory surge of LH (Fig. 6). Therefore, if CRF plays a role in reproductive inhibition by

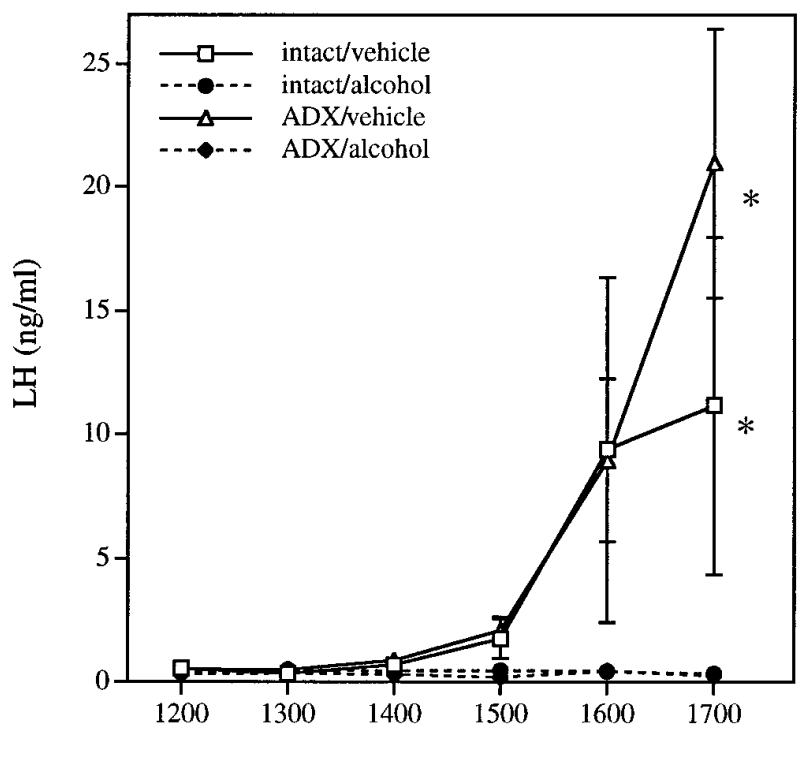

Time (h)

Figure 6. Alcohol blocks the proestrous LH surge and ovulation in ADX female rats. Alcohol blocked the LH surge in intact ( $20 \%$ ovulatory rate) and $\operatorname{ADX}(0 \%$ ovulation) animals, whereas female rats injected with vehicle had robust increases in LH (ovulatory rates of 100 and $60 \%$ for intact and ADX females, respectively). Each point represents the mean \pm SEM of four to five animals. *, Vehicle-treated groups differed from alcohol-treated groups, but did not differ from each other $(p<0.05$; least squares means post hoc test). alcohol, that role is independent of its influence on peripheral HPA hormone levels.

Many other neuronal systems are candidates through which alcohol may exert its influence on the reproductive system of the female. Among these are NMDA, GABA, and opiate-dependent systems within the POA and hypothalamus. Immortalized LHRH cells (GT1 cells) in culture express all of these receptor subtypes, with NMDA receptor activation resulting in secretion of LHRH (Mahachoklertwattana et al., 1994), whereas opioid receptors

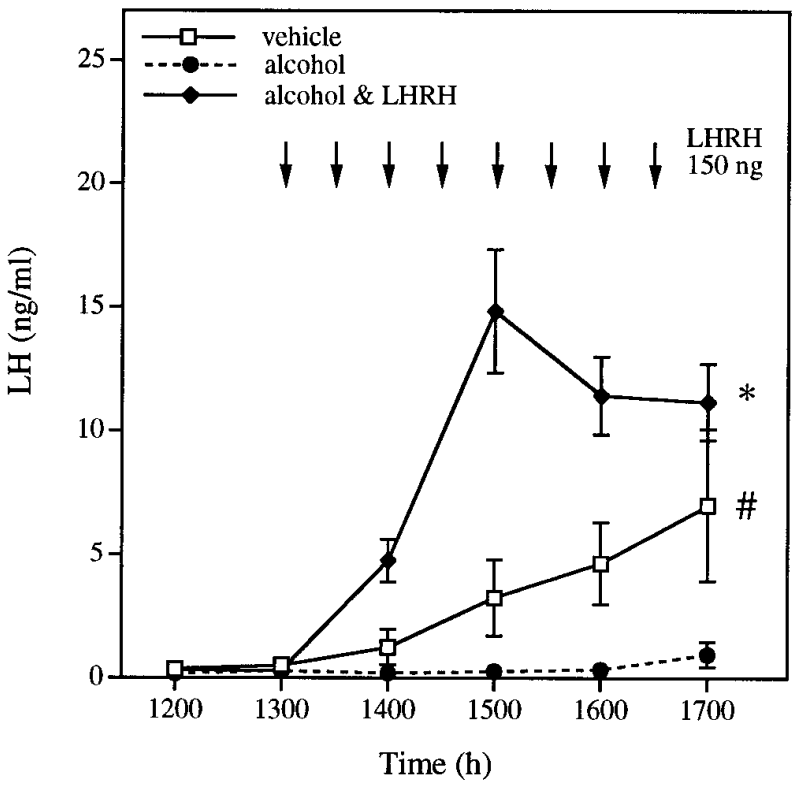

Figure 7. LHRH administration restores the surge of LH and ovulation in animals treated with alcohol. Alcohol blocked the preovulatory LH surge (41.7\% ovulation). Administration of pulses of LHRH (indicated by arrows on graph) to animals treated previously with alcohol reinstated $\mathrm{LH}$ secretion and ovulation (ovulatory rate of $100 \%$ ). Each point represents the mean \pm SEM of 9-12 rats. *, Animals treated with alcohol \& LHRH differ significantly from the other two groups, whereas \# indicates that female rats treated with alcohol alone also differ from females treated with vehicle ( $p<0.01$; least squares means post hoc test). 
(Maggi et al., 1995a,b) play an inhibitory role. GABA, on the other hand, can alter LHRH secretion in either direction, depending on the receptor subtype that is activated (Martinez de la Escalera et al., 1994). Because these receptor systems have been implicated in the effects of alcohol on behavior (for review, see Grant, 1994; Nevo and Hamon, 1995; Koob, 1996), it is possible that alcohol acts on these receptors within reproductive neuroendocrine centers in a similar manner. Although much remains to be done, data gathered in male rats suggest involvement of opioidergic systems (Cicero et al., 1982), whereas investigations in prepubertal female rats implicate NMDA-dependent mechanisms (Nyberg et al., 1995).

In conclusion, we have shown that acute administration of alcohol results in a profound inhibition of the reproductive axis in the female rat, including suppression of ovulation, blockade of the preovulatory surges of $\mathrm{LH}$ and LHRH, and perturbation of steroid hormone secretion. Our data demonstrate that alcohol exerts this effect primarily within the CNS, rather than through a direct pituitary or gonadal influence. Alcohol impairs generation of the gonadotropin surge for longer than $24 \mathrm{hr}$, suggesting that this drug affects reproductive neuroendocrine centers more intensely than barbiturates. The precise mechanism by which alcohol prevents the activation of LHRH neurons remains to be determined.

\section{REFERENCES}

Adams ML, Cicero TJ (1991) Effects of alcohol on $\beta$-endorphin and reproductive hormones in the male rat. Alcohol Clin Exp Res 15:685-692.

Akane A, Fukushima S, Shiono H, Fukui Y (1988) Effects of ethanol on testicular steroidogenesis in the rat. Alcohol Alcohol 23:203-209.

Alfonso M, Durán R, Marcó J (1993a) Ethanol-induced alterations in gonadotrophins secretion during the estrous cycle of rats. Alcohol Alcohol 26:667-674.

Alfonso M, Durán R, Marcó J (1993b) In vitro effect of ethanol on LH and FSH secretion by pituitary glands of female rats. Endocrine Res 19:175-186.

Banks JA, Freeman ME (1978) The temporal requirement of progesterone on proestrus for extinction of the estrogen-induced daily signal controlling luteinizing hormone release in the rat. Endocrinology 102:426-432.

Bauer-Dantoin AC, McDonald JK, Levine JE (1991) Neuropeptide Y potentiates luteinizing hormone (LH)-releasing hormone-stimulated LH surges in pentobarbital-blocked proestrous rats. Endocrinology 129:402-408.

Butcher RL, Collins WE, Fugo NW (1974) Altered secretion of gonadotropins and steroids resulting from delayed ovulation in the rat. Endocrinology 96:576-586.

Canteros G, Rettori V, Franchi A, Genaro A, Cebral E, Faletti A, Gimeno M, McCann SM (1995) Ethanol inhibits luteinizing hormone-releasing hormone (LHRH) secretion by blocking the response of LHRH neuronal terminals to nitric oxide. Proc Natl Acad Sci USA 92:3416-3420.

Ching M, Valenca M, Negro-Vilar A (1988) Acute ethanol treatment lowers hypophyseal portal plasma luteinizing hormone-releasing hormone (LHRH) and systemic plasma LH levels in orchidectomized rats. Brain Res 443:325-328.

Cicero TJ, Bell RD (1982) Ethanol-induced reductions in testicular steroidogenesis: major differences between in vivo and in vitro approaches. Steroids 40:561-568.

Cicero TJ, Bernstein D, Badger TM (1978) Effects of acute alcohol administration on reproductive endocrinology in the male rat. Alcohol Clin Exp Res 2:249-254.

Cicero TJ, Meyer ER, Bell RD (1979) Effects of ethanol on the hypothalamic-pituitary-luteinizing-hormone axis and testicular steroidogenesis. J Pharmacol Exp Ther 208:210-215.

Cicero TJ, Newman KS, Gerrity M, Schmoeker PF, Bell RD (1982) Ethanol inhibits the naloxone-induced release of luteinizing hormonereleasing hormone from the hypothalamus of the male rat. Life Sci 31:1587-1596.

Cobb CF, Ennis MF, Van Thiel DH, Gavaler JS, Lester R (1980) Isolated testes perfusion: a method using a cell- and protein-free perfusate useful for the evaluation of potential drug and/or metabolic injury. Metabolism 29:71-79.

Dees WL, Kozlowski GP (1984) Differential effects of ethanol on luteinizing hormone, follicle stimulating hormone and prolactin secretion in the female rat. Alcohol 1:429-433.

Dees WL, McArthur NH, Farr KL, Culler MD, Harms PG (1983) Effects of ethanol on rat hypothalamic luteinizing hormone releasing hormone: a study utilizing radioimmunoassay. Biol Reprod 28:1066-1070.

Dees WL, Rettori V, Kozlowski GP, McCann SM (1985) Ethanol and the pulsatile release of luteinizing hormone, follicle stimulating hormone and prolactin in ovariectomized rats. Alcohol 2:641-646.

DePaolo LV, Barraclough CA (1979a) Dose dependent effects of progesterone on the facilitation and inhibition of spontaneous gonadotropin surges in estrogen treated ovariectomized rats. Biol Reprod 21:1015-1023.

DePaolo LV, Barraclough CA (1979b) Interactions of estradiol and progesterone on pituitary gonadotropin secretion: possible sites and mechanisms of action. Biol Reprod 20:1173-1185.

Emanuele MA, Hojvat S, Emanuele NV, Zelke S, Kirsteins L, Lawrence AM (1986) The effect of alcohol on quantitative and qualitative changes in luteinizing hormone (LH) in the female rat. Endocrine Res 12:123-136.

Emanuele MA, Tentler J, Reda D, Kirsteins L, Emanuele NV, Lawrence AM (1990) The effect of in vitro ethanol exposure on LHRH release from perifused rat hypothalami. Endocrine Res 16:313-321.

Emanuele MA, Tentler J, Emanuele NV, Kelley MR (1991) In vivo effects of acute EtOH on rat and luteinizing hormone gene expression. Alcohol 8:345-348.

Everett JW, Sawyer CH (1950) A $24 \mathrm{hr}$ periodicity in the "lh-release apparatus" of female rats, disclosed by barbiturate sedation. Endocrinology 47:198-218.

Gonzalez-Reimers E, Martinez-Riera A, Santolaria-Fernandez F, CondeMartel A, Alvarez-Argüelles H, Santana-Herrera C, RodriguezMoreno F (1994) Relative and combined effects of ethanol and protein deficiency on gonadal function and histology. Alcohol 11:355-360.

Grant KA (1994) Emerging neurochemical concepts in the actions of ethanol at ligand-gated ion channels. Behav Pharmacol 5:383-404.

Grattan DR, Park S-K, Selmanoff M (1995) Orchidectomy and NMDA increase GnRH secretion as measured by push-pull perfusion of rat anterior pituitary. Am J Physiol 268:E685-E692.

Hiney JK, Dees WL (1991) Ethanol inhibits luteinizing hormonereleasing hormone release from the median eminence of prepubertal female rats in vitro: investigation of its actions on norepinephrine and prostaglandin- $\mathrm{E}_{2}$. Endocrinology 128:1404-1408.

Ida Y, Tsujimaru S, Nakamaura K, Shirao I, Mukasa H, Egami H, Nakazawa Y (1992) Effects of acute and repeated alcohol ingestion on hypothalamic-pituitary-gonadal and hypothalamic-pituitary-adrenal functioning in normal males. Drug Alcohol Depend 31:57-64.

Inukai T, Wang X, Greer MA, Greer SE (1993) Isotonic but not hypertonic ethanol stimulates LHRH secretion from perifused rat median eminence. Neuroendocrinology 58:258-262.

Kalra SP (1975) Observations of facilitation of the preovulatory rise of LH by estrogen. Endocrinology 96:23-28.

Kalra SP (1993) Mandatory neuropeptide-steroid signaling for the preovulatory luteinizing hormone-releasing hormone discharge. Endocr Rev 14:507-538.

Kalra SP, Kalra PS (1974) Temporal interrelationships among circulating levels of estradiol, progesterone and LH during the rat estrous cycle: effects of exogenous progesterone. Endocrinology 95:1711-1718.

Kim C-Y, Wakabayashi K, Nobunga T (1994) Time-dependent ovulation-blocking effect of ether anesthesia differs from pentobarbital in rats. Tohoku J Exp Med 172:237-242.

Koob GF (1996) The neuropharmacology of ethanol's behavioral action: new data, new paradigms, new hope. In: Pharmacological effects of ethanol on the nervous system (RA Deitrich, VG Erwin, eds), pp 1-12. New York: CRC.

Lafuente A, Arce A, López M, Carro E, Marcó J, Esquifino AI (1994) Acute ethanol administration in diestrus- 2 in the rat on pulsatile prolactin and LH release. Pharmacol Biochem Behav 49:789-794.

Lee W-S, Smith MS, Hoffman GE (1990) Luteinizing hormone-releasing hormone neurons express Fos protein during the proestrous surge of luteinizing hormone. Proc Natl Acad Sci USA 87:5163-5167.

Levine JE, Powell KD (1989) Microdialysis for measurement of neuroendocrine peptides. Methods Enzymol 168:166-181.

Levine JE, Ramirez VD (1982) Luteinizing hormone-releasing hormone 
release during the rat estrous cycle and after ovariectomy as estimated with push-pull cannulae. Endocrinology 111:1439-1448.

Levine JE, Wolfe AM, Porkka-Heiskanen T, Meredith JM, Norgle JR, Turek FW (1994) In vivo sampling and administration of hormone pulses in rodents. Methods Neurosci 20:129-161.

Little PJ, Adams ML, Cicero TJ (1992) Effects of alcohol on the hypothalamic-pituitary-gonadal axis in the developing male rat. J Pharmacol Exp Ther 263:1056-1061.

Maggi R, Pimpinelli F, Martini L, Piva F (1995a) Characterization of functional opioid delta receptors in a luteinizing hormone-releasing hormone-producing neuronal cell line. Endocrinology 136:289-295.

Maggi R, Pimpinelli F, Martini L, Piva F (1995b) Inhibition of luteinizing hormone-releasing hormone secretion by $\delta$-opioid agonists in GT- 1 neuronal cells. Endocrinology 136:5177-5181.

Mahachoklertwattana P, Sanchez J, Kaplan SL, Grumbach MM (1994) (NMDA) receptors mediate the release of gonadotropin-releasing hormone $(\mathrm{GnRH})$ by NMDA in a hypothalamic GnRH neuronal cell line (GT1-1). Endocrinology 134:1023-1030.

Marcó J, Parafita MA, Alfonso M, Espinosa J (1984) Changes in serum LH and FSH following preovulatory administration of ethanol in rats. Drug Alcohol Depend 14:215-218.

Martinez de la Escalera G, Choi ALH, Weiner RI (1994) Biphasic gabaergic regulation of $\mathrm{GnRH}$ secretion in $\mathrm{GT}_{1}$ cell lines. Neuroendocrinology 59:420-425.

McKenzie PP, McClaran JD, Caudle MR, Fukuda A, Wimalasena J (1995) Alcohol inhibits epidermal growth factor-stimulated progesterone secretion from human granulosa cells. Alcohol Clin Exp Res 19:1382-1388.

Mello NK, Mendelson JH, Teoh SK (1989) Neuroendocrine consequences of alcohol abuse in women. Ann NY Acad Sci 562:211-240.

Mello NK, Mendelson JH, Teoh SK (1993) An overview of the effects of alcohol on neuroendocrine function in women. In: Alcohol and the endocrine system (S Zakhari, ed), pp 139-170. Bethesda, MD: NIH.

Nevo I, Hamon M (1995) Neurotransmitter and neuromodulatory mechanisms involved in alcohol abuse and alcoholism. Neurochem Int 26:305-336.

Nishimori K, Yamoto M, Nakano R (1993) In vitro effects of ethanol on gonadotropin-binding sites in porcine granulosa cells. Exp Clin Endocrinol 101:238-242.

Nyberg CL, Srivastava V, Hiney JK, Lara F, Dees WL (1995) $N$-methyl-D-aspartic acid receptor messenger ribonucleic acid levels and luteinizing hormone release in immature female rats: effects of stage of pubertal development and exposure to ethanol. Endocrinology 136:2874-2880.

Ogilvie KM, Rivier C (1996) Gender difference in alcohol-evoked hypothalamic-pituitary-adrenal activity in the rat: ontogeny and role of neonatal steroids. Alcohol Clin Exp Res 20:255-261.

Ogilvie KM, Lee S, Rivier C (1997) Role of vasopressin (AVP) and corticotropin-releasing factor in mediating alcohol-induced ACTH and AVP secretion in male rats bearing lesions of the paraventricular nuclei. Brain Res 744:83-95.

Orpana AK, Härkönen M, Eriksson JP (1990) Ethanol-induced inhibition of testosterone biosynthesis in rat Leydig cells: role of mitochondrial substrate shuttles and citrate. Alcohol Alcohol 25:499-507.

Paxinos G, Watson C (1986) The rat brain in stereotaxic coordinates, 2nd ed. San Diego: Academic.

Rettori V, Skelley CW, McCann SM, Dees WL (1987) Detrimental effects of short-term ethanol exposure on reproductive function in the female rat. Biol Reprod 37:1089-1096.

Rivest S, Rivier C (1993) Interleukin-1 inhibits the endogenous expression of the early gene c-fos located within the nucleus of LHRH neurons and interferes with hypothalamic LHRH release during proestrus in the rat. Brain Res 613:132-142.

Rivest S, Rivier C (1994) Lesions of hypothalamic PVN partially attenuate the stimulatory action of alcohol on ACTH secretion in rats. Am J Physiol 266:R553-R558.

Rivest S, Plotsky PM, Rivier C (1993) CRF alters the infundibular LHRH secretory system from the medial preoptic area of female rats: possible involvement of opioid receptors. Neuroendocrinology 57:236-246.

Rivier C (1993) Female rats release more corticosterone than males in response to alcohol: influence of circulating sex steroids and possible consequences for blood alcohol levels. Alcohol Clin Exp Res 17:854-859.

Rivier C, Lee S (1996) Acute alcohol administration stimulates the activity of hypothalamic neurons that express corticotropin-releasing factor and vasopressin. Brain Res 726:1-10.

Rivier C, Vale W (1983) Influence of ethanol on reproductive functions of the adult male rat as a function of body weight. Alcohol Clin Exp Res 7:210-212.

Rivier C, Bruhn T, Vale W (1984) Effect of ethanol on the hypothalamicpituitary-adrenal axis in the rat: role of corticotropin-releasing factor (CRF). J Pharmacol Exp Ther 229:127-131.

Rivier C, Rivest S, Vale W (1992) Alcohol-induced inhibition of LH secretion in intact and gonadectomized male and female rats: possible mechanisms. Alcohol Clin Exp Res 16:935-941.

Roozendaal MM, Swarts HJM, Wiegant VM, Mattheij JAM (1995) Effect of restraint stress on the preovulatory luteinizing hormone profile and ovulation in the rat. Eur J Endocrinol 133:347-353.

Sagar SM, Sharp FR, Curran T (1988) Expression of c-fos protein in brain: metabolic mapping at the cellular level. Science 240:1328-1331.

Salonen I, Huhtaniemi I (1990) Effects of chronic ethanol diet of pituitary-testicular function of the rat. Biol Reprod 42:55-62.

Salonen I, Pakarinen P, Huhtaniemi I (1992) Effect of chronic ethanol diet on expression of gonadotropin genes in the male rat. $\mathrm{J}$ Pharmacol Exp Ther 260:463-467.

Santucci L, Graham TJ, Van Thiel DH (1983) Inhibition of testosterone production by rat Leydig cells with ethanol and acetaldehyde: prevention of ethanol toxicity with 4-methylpyrazole. Alcohol Clin Exp Res 7:135-139.

Sarkar DK, Minami S (1995) Diurnal variation in luteinizing hormonereleasing hormone and beta-endorphin release in pituitary portal plasma during the rat estrous cycle. Biol Reprod 53:38-45.

Sarkar DK, Chiappa SA, Fink G, Sherwood NM (1976) Gonadotropinreleasing hormone surge in pro-oestrous rats. Nature 264:461-463.

Schade RR, Bonner G, Gay VC, Van Thiel DH (1983) Evidence for a direct inhibitory effect of ethanol upon gonadotropin secretion at the pituitary level. Alcohol Clin Exp Res 7:150-152.

Silverman A-J, Witkin JW, Millar RP (1990) Light and electron microscopic immunocytochemical analysis of antibodies directed against GnRH and its precursor in hypothalamic neurons. J Histochem Cytochem 38:803-813.

Subramanian MG, Savoy-Moore RT, Bergeski BA, Kruger ML, Abel E (1990) Acute alcohol infusion does not alter plasma gonadotropins or prolactin in ovariectomized rats. Alcohol Clin Exp Res 14:191-194.

Uddin S, Emanuele MA, Emanuele NV, Reda D, Kelley MR (1994) The effect of in vitro ethanol exposure on luteinizing hormone and follicle stimulating hormone mRNA levels, content, and secretion. Endocrine Res 20:201-217.

Van Thiel DH, Gavaler JS (1982) The adverse effects of ethanol upon hypothalamic-pituitary-gonadal function in males and females compared and contrasted. Alcohol Clin Exp Res 6:179-185.

Van Thiel DH, Cobb CF, Herman GB, Perez HA, Estes L, Gavaler JS (1981) An examination of various mechanisms for ethanol-induced testicular injury: studies utilizing the isolated perfuse rat testes. Endocrinology 109:2009-2015.

Weiland NG, Scarbrough K, Wise PM (1992) Aging abolishes the estradiol-induced suppression and diurnal rhythm of proopiomelanocortin gene expression in the arcuate nucleus. Endocrinology 131:2959-2964.

Widenius TV (1987) Ethanol-induced inhibition of testosterone biosynthesis in vitro: lack of acetaldehyde effect. Alcohol Alcohol 22:17-22.

Wimalasena J, Meehan D, Dostal R, de Silva M (1993) Selective inhibition of luteinizing hormone action by ethanol in cultured human granulosa cells. Alcohol Clin Exp Res 17:340-344. 